\title{
Over-expression and Purification of Recombinant Methylparathion Degrading Enzyme by Lactose Induction
}

\author{
Yongze Yuan*, Xueting Yang*, Junzhong Yang, Jianhua Zhang, Shangying Xu, Kehan Xu, Lixia Zeng, \\ Deli Liu** \\ Hubei Key Laboratory of Genetic Regulation and Integrative Biology, College of Life Science, Central China Normal \\ University, Wuhan, China,430079; \\ (*Contributed equally; ** Corresponding author E-mail: deliliu2002@yahoo.com.cn)
}

\begin{abstract}
Organophosphorus (OP) degrading enzymes were widely used in economical and safe detoxification of organophosphorus pesticides from soil, water, food, and aquatic product. In this study, a novel methylparathion degrading enzyme (MPD) was over-expressed in Escherichia coli BL21 (DE3) as a His-tagged fusion protein by the use of lactose as inducer instead of IPTG. SDS-PAGE combined with enzyme activity analysis indicated that lactose-induced expression yield of active MPD was increased nearly 2-fold compared with IPTG as inducer. The optimum temperature and concentration for lactose induction was $37^{\circ} \mathrm{C}$ and $0.5 \%$ (w/v), respectively. The expressed fusion proteins induced by the two inducers were both purified by Ni-metal-affinity chromatography. The specific activity of the purified recombinant MPD induced by lactose, reaching at 140 $\mu \mathrm{mol} \cdot \mathrm{min}^{-1} \cdot \mathrm{mg}^{-1}$, was nearly 0.5 -fold higher than that of the purified enzyme induced by IPTG. Thus, lactose was a well alternative inducer to produce active MPD and gave an advantage over enzyme purification. This study suggested a more effective method to produce purified MPD, an ideal enzyme to detoxify OP pesticides for ecosystem restoration.
\end{abstract}

Keywords-ethylparathion degrading enzyme; pollutant detoxification; Lactose inducer; Enzyme purification.

\section{I . INTRODUCTION}

Organophosphorus pesticides (OPs), widely used as a large group of pesticides in agriculture, are regarded as the main pollution sources due to their severe toxicity to environment as well as to human beings [1]. The microbial degradation of OPs offers a promising strategy to solve the problems by screening organophosphorous degrading microorganisms as well as using bacterial enzymes. Methylparathion-degrading gene ( $m p d$ ) has been intensively investigated and widely used in ecosystem restoration [2-5]. We previously cloned $m p d$ gene from a novel organophosphorous-degrading bacterium naming HS-D36 and the intact $m p d$ gene was expressed in E.coli by using pET expression system [6].

IPTG, the typical inducer for heterologous gene expression in E.coli expression systems, has main drawback of its high expense and toxicity to organisms. Lactose, the natural inducer for the lac operon, is therefore exploited to instead IPTG, especially in large scale fermentations [7-8].

In our previous research, the recombinant MPD induced by IPTG predominantly expressed as insoluble inclusion bodies. It significantly reduced the yield of active MPD as well as the purified MPD. In order to improve the efficiency of active MPD expression and purification for environmental pollutant detoxification, in this paper, we choose lactose as an alternative inducer to produce recombinant MPD in E.coli cells and purified the lactose induced proteins by Ni-metal affinity chromatography. 


\section{II . MATERIALS AND METHODS}

\section{A. Strains, plasmids, and chemicals}

The bacterial strain HS-D36 containing the mpd gene, E.coli BL21 (DE3) used as heterologous expression hosts and plasmid pET-28a used for over-expression of recombinant MPD were stored in our laboratory. Enzymes for molecular cloning were purchased from TaKaRa. Other regents including IPTG and lactose were purchased form Wuhan Yixin Biotech. Co. Plasmid pMD-mpd, the source of the mpd gene, and the expression recombinant plasmid pET-mpd were constructed as described previously [6].

\section{B. Expression of recombinant MPD by induction of IPTG or lactose}

BL21 (DE3) strains harboring pET-mpd were activated overnight followed by transferring and growing in LB medium plus $50 \mu \mathrm{g} \cdot \mathrm{ml}^{-1}$ kanamycin at $37{ }^{\circ} \mathrm{C}$ to the optimum density $\left(\mathrm{OD}_{600}=0.6\right)$. IPTG was added at a final concentration of $1.0 \mathrm{mmol} \cdot \mathrm{L}^{-1}$ as inducer to produce the recombinant MPD. Meanwhile, lactose, an alternative inducer, was added from its stock solution to give the desired concentrations $(\mathrm{w} / \mathrm{v})$ of $0.05 \%, 0.1 \%, 0.2 \%, 0.5 \%$, and $1.0 \%$. Recombinant E.coli cells were harvested after 2- $16 \mathrm{~h}$ of induction. For lactose experiments, the temperature was reduced to 28 or $20{ }^{\circ} \mathrm{C}$ at the time point of induction. All the samples were harvested by centrifuging at $10,000 \mathrm{~g}$ for $10 \mathrm{~min}$ and the expressed proteins were analyzed by SDS-PAGE.

\section{Purification of His6-tagged MPD}

The over-expressed $\mathrm{His}_{6}$-tagged MPD by $8 \mathrm{~h}$ induction of $1 \mathrm{mM}$ IPTG or $0.1 \%(\mathrm{w} / \mathrm{v})$ lactose was determined by analysis of SDS-PAGE before purification by affinity chromatography. The HisTrap affinity column (1-ml) purchased from GE Healthcare was used for one-step purification of the recombinant MPD by using AKTA purifier system (GE Healthcare).

For the preparation of the crude enzyme, 1) the induced E.coli BL21 (DE3) cells harboring pET-mpd were harvested from 1.0 L cultures by centrifugation $(10,000 \mathrm{~g}$, $\left.4{ }^{\circ} \mathrm{C}, 10 \mathrm{~min}\right)$; 2) the cell pellets were resuspended in binding buffer $\left(20 \mathrm{mmol} \cdot \mathrm{L}^{-1}\right.$ Tris- $\mathrm{HCl}, 500 \mathrm{mmol} \cdot \mathrm{L}^{-1}$ $\mathrm{NaCl}$, and $5 \mathrm{mmol} \cdot \mathrm{L}^{-1}$ imidazole, $\mathrm{pH} 8.3$ ) at $10 \mathrm{ml} \cdot \mathrm{g}^{-1}$ of wet cells; 3 ) this cell suspension with the adding of 0.1 $\mathrm{mmol} \cdot \mathrm{L}^{-1}$ (final concentration) PMSF (protease inhibitor) was sonicated for about $5 \mathrm{~min}$ until the mixture was no longer viscous; and 4) the lysate was centrifuged $(12,000 \mathrm{~g}$, $4{ }^{\circ} \mathrm{C}, 15 \mathrm{~min}$ ) to remove the debris.

The supernatant was subjected to a 1-ml Ni-metal-affinity column which had been equilibrated with the binding buffer. After washing with $20 \mathrm{ml}$ washing buffer $\left(20 \mathrm{mmol} \cdot \mathrm{L}^{-1}\right.$ Tris- $\mathrm{HCl}, 500 \mathrm{mmol} \cdot \mathrm{L}^{-1}$ $\mathrm{NaCl}$, and $5 \mathrm{mmol} \cdot \mathrm{L}^{-1}$ imidazole, $\mathrm{pH} 8.3$ ), His $_{6}$-tagged MPD was eluted from the column with elution buffer (20 $\mathrm{mmol} \cdot \mathrm{L}^{-1}$ Tris $-\mathrm{HCl}, 500 \mathrm{mmol} \cdot \mathrm{L}^{-1} \mathrm{NaCl}$, and $90 \mathrm{mmol} \cdot \mathrm{L}^{-1}$ imidazole, $\mathrm{pH}$ 8.3). The purified enzyme was subjected to specific activity determination for access of purification efficiency.

\section{Assay of MPD activity}

$1 \mathrm{ml}$ of MPD activity assay mixture was consisted of $50 \mu \mathrm{l}$ methyl parathion (MP) $\left(2 \mathrm{mg} \cdot \mathrm{ml}^{-1}\right), 850 \mu \mathrm{l}$ assay buffer $\left(50 \mathrm{mmol} \cdot \mathrm{L}^{-1}\right.$ Tris- $\left.\mathrm{HCl}, \mathrm{pH} 8.9\right)$, and $100 \mu \mathrm{l}$ of crude enzyme MPD. A solution without the crude enzyme was set as a negative control. The rate of p-nitrophenol (PNP) release at room temperature in the dark was spectrophotometrically measured at $405 \mathrm{~nm}$ to determine MPD activity. One unit (U) of activity is defined as the formations of $1 \mu \mathrm{mol}$ PNP per minute.

\section{E. Assay of soluble protein content}

The concentration of total soluble proteins was determined according to the method described by Bradford [9] using BSA as the standard.

\section{RESULTS AND DISCUSSION}

\section{A. Over-expression of recombinant MPD by lactose} induction

In E.coli expression system, the natural inducer of lac operon is lactose which has been used in large-scale fermentations [7]. In this study, we tested whether recombinant MPD could be expressed at high level in 
E.coli BL21 (DE3) cells with lactose inducer.

As shown in Fig.1, 8-16 $\mathrm{h}$ induction of IPTG and lactose could both make recombinant E.coli BL21 (pET-mpd) produce an over-expressed protein with the molecular weight of $35 \mathrm{kD}$ which was identical to the calculated mass of MPD. Thus, lactose could be used to instead IPTG for inducing recombinant MPD in BL21 (DE3). Interestingly, as observed in SDS-PAGE, another protein (about $37 \mathrm{kD}$ ) which band located a little upper to the $35 \mathrm{kD}$ protein was also over-expressed with the lactose induction. Here, whether the two over-expressed protein bands around $35 \mathrm{kD}$ were two different forms of $m p d$ gene product needed further identification, such as western blotting analysis.

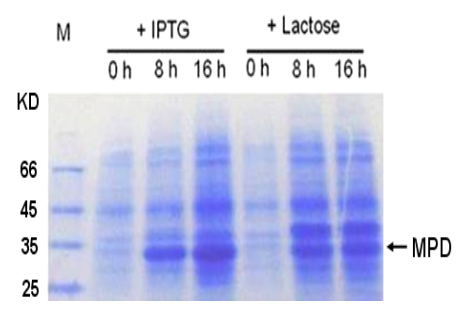

Figure 1. SDS-PAGE analysis of recombinant MPD expressed in BL21 (DE3) by IPTG or lactose induction. M: standard protein molecular weight $(\mathrm{KD})$; the final concentrations of IPTG and lactose used in induction media were $1.0 \mathrm{mM}$ and $0.1 \%(\mathrm{w} / \mathrm{v})$, respectively; 0,8 , and $16 \mathrm{~h}$ were expressed as induction time points.

Nevertheless, in this study, the use of different dose of lactose (w/v) from $0.05 \%$ to $1.0 \%$ as the inducer at $37{ }^{\circ} \mathrm{C}$ all obtained higher enzyme activity compared to that of IPTG induction (data not shown). Under the optimum conditions for lactose induction (Fig.2), the activity of recombinant MPD reached to $83.9 \mathrm{U} / \mathrm{ml}$, which was nearly $60 \%$ higher than that in IPTG induction $(52.5 \mathrm{U} / \mathrm{ml}$; see reference [6]). Therefore, lactose induction favored the yield of active MPD. As reported previously [10], recombinant protein expression in E.coli by IPTG induction often resulted in the accumulation of large amounts of unfolded proteins in the form of insoluble inclusion body. This would be more or less reduced in lactose induction, as described in our present experiments.

The optimum conditions for lactose induction were investigated in this paper. As shown in Fig.2, the optimum temperature and induction time were $37^{\circ} \mathrm{C}$ and $8 \mathrm{~h}$,
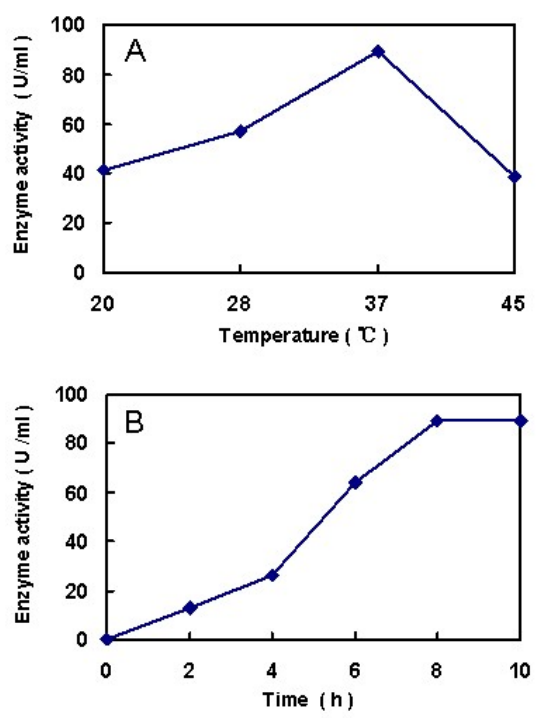

Figure 2. Effect of temperature (A) and induction time (B) on the activity of recombinant MPD expressed in BL21 (DE3) by lactose induction. The final concentration of lactose in induction systems were $0.5 \%(\mathrm{w} / \mathrm{v})$.

respectively, with $0.5 \%(\mathrm{w} / \mathrm{v})$ of lactose. It yielded the maximum MPD activity of $83.9 \mathrm{U} / \mathrm{ml}$ at $37^{\circ} \mathrm{C}$ for $8 \mathrm{~h}$. However, the yield of active MPD for the same induction time was deduced by $32 \%$ at $28{ }^{\circ} \mathrm{C}$, and by $51 \%$ at $20^{\circ} \mathrm{C}$. At the lower temperatures, the recombinant E.coli cell density decreased in accordance (data not shown). The optimum lactose concentration for the induction of MPD expression in our study was $0.5 \%(\mathrm{w} / \mathrm{v})$ or below. Higher concentrations of lactose (above 1.0\%) inhibited protein expression, which was also observed in MPH expression induced by lactose [11]. This decrease in enzyme expression was assumed to a result of lactose metabolism, but not due to cell death or E.coli growth restriction, for there was no negative change in cell density.

\section{B. Purification of His6-tagged MPD}

The expressed His $_{6}$-tagged MPD induced by IPTG as well as lactose were both subjected to Ni-affinity chromatography for the enzyme purification. The crude extracts after sonication were applied to the Ni-NTA column under non-denaturing conditions. As shown in Fig.3, undesired proteins were washed away with buffer containing $5 \mathrm{mmol} \cdot \mathrm{L}^{-1}$ imidazole, and $\mathrm{His}_{6}$-tagged MPD 
was eluted with buffer containing $90 \mathrm{mmol} \cdot \mathrm{L}^{-1}$ imidazole.

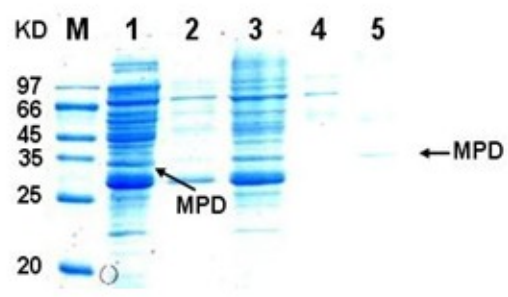

Figure 3. SDS-PAGE analysis of recombinant MPD purification by $\mathrm{Ni}^{2+}$-affinity chromatography. $\mathrm{M}$ : standard protein molecular weight (KD); Lane 1: enzymatic supernatant extracted from BL21 (DE3) cells harboring pET-mpd with lactose induction; Lane 2: proteins not binding to $\mathrm{Ni}^{2+}$-affinity column; Lane 3 : undesired proteins washed away with washing buffer; Lane 4: proteins eluted by buffer containing 30 $\mathrm{mmol} \cdot \mathrm{L}^{-1}$ imidazole; Lane 5: proteins eluted by buffer containing 90 $\mathrm{mmol} \cdot \mathrm{L}^{-1}$ imidazole.

Further, the specific activity of purified MPD using lactose as inducer was increased by 1.5 -fold compared to that using IPTG as inducer (Table 1). It was assumed to be resulted from more yield of active MPD in lactose induction. Several organophosphorus hydrolases have been reported to be purified with specific activities of not more than $100 \mathrm{U} / \mathrm{mg}[3,12]$. In our study, the specific activity of MPD induced by lactose reached at 150.7 $\mathrm{U} / \mathrm{mg}$. It suggested that lactose induction system could be a well alternative to produce recombinant MPD for enzyme purification with higher efficiency.

Table 1. Purification of recombinant MPD by Ni-metal-affinity chromatography

\begin{tabular}{cccc}
\hline \multirow{2}{*}{ Enzyme } & \multicolumn{2}{c}{$\begin{array}{c}\text { Specific activity } \\
\text { ( U/mg protein) }\end{array}$} & Fold \\
\cline { 2 - 3 } & $\begin{array}{ccc}\text { Before } \\
\text { purification }\end{array}$ & purification & \\
\hline MPD induced by IPTG & 30.8 & 72.4 & 2.4 \\
MPD induced by lactose & 41.2 & 150.7 & 3.7 \\
\hline
\end{tabular}

\section{IV . CONCLUSION}

The results presented in this paper demonstrated the over-expression of the recombinant MPD by lactose induction. The optimum temperature and inducer concentration were $37{ }^{\circ} \mathrm{C}$ and $0.5 \%(\mathrm{w} / \mathrm{v})$, respectively.
The lactose induction could produce more active MPD protein and yield better purified recombinant enzymes by using Ni-metal affinity chromatography. Here, we reported a more efficient method to express and purify MPD for OP pesticide detoxification in practice.

\section{ACKNOWLEDGEMENTS}

This work was partially supported by National Natural Science Foundation of China (30771429); The National High Technology Research and Development Program of China (2007AA05Z417); Specialized Research Fund for the Doctoral Program of Higher Education (20060511002) and by the Construction Fund for "211" Project of the Ministry of Education of China.

\section{REFERENCES}

[1] Singh BK, Walker A. Microbial degradation of organophosphorus compounds. FEMS Microbiol Rev, 2006, 30: 428-471

[2] Cui ZL, Li SP, Fu GP. Isolation of methyl parathion degrading strain M6 and cloning of the methyl parathion hydrolase gene. Appl Environ Microbiol, 2001, 67: 4922-4925

[3] Fu GP, Cui ZL, Huang T, Li SP. Expression, purification, and characterization of a novel methyl parathion hydrolase. Protein Expr Purif, 2004, 36: 170-176

[4] Yang C, Liu N, Guo X, Qiao C. Cloning of mpd gene from a chlorpyrifos-degrading bacterium and use of this strain in bioremediation of contaminated soil. FEMS Microbiol Lett, 2006, 265: 118-125

[5] Zhang R, Cui ZL, Zhang X, Jiang J, Gu J, Li SP. Cloning of the organophosphorus pesticide hydrolase gene clusters of seven degradative bacteria isolated from a methyl parathion contaminated site and evidence of their horizontal gene transfer. Biodegradation, 2006, 17: 465-472

[6] Wang BB, Xiong L, Zheng YL, Zhang ZX, Tong WY, Liu S, Chen YH, Xiao WJ, Liu DL. Cloning and expression of the mpd gene from a newly isolated methylparathion-degrading strain of bacteria. Acta Scientiae Circumstantiae, 2008, 28: 1969-1975

[7] Neubauer P, Hofmann K. Efficient use of lactose for the lac promoter-controlled overexpression of the main anti-genic protein of the foot and mouth disease virus in E. coli under fed-batch fermentation conditions. FEMS Microbiol Rev, 1994, 14: 99-102

[8] Monteiro R, Souza EM, Yates MG, Pedrosa FO, Chubatsu LS. Use of lactose to induce expression of soluble NifA protein domains of Herbaspirillum seropedicae in E. coli. Can J Microbiol, 2000, 46: 1087-1090

[9] Bradford MM. A rapid and sensitive method for the quantitation of microgram quantities of protein utilizing the principle of protein-dye binding. Anal Biochem, 1976, 72: 248-254

[10] Schein CH, Noteborn MHM. Formation of soluble recombinant proteins in E. coli is favored by lower growth temperature. Biotechnology, 1988, 6: 291-294

[11] Yang JJ, Yang C, Jiang H, Qiao CL. Overexpression of methyl parathion hydrolase and its application in detoxification of organophosphates. Biodegradation, 2008, 19: 831-839

[12] Chu XY, Wu NF, Deng MJ, Tian J, Yao B, Fan YL. Expression of organophosphorus hydrolase OPHC2 in Pichia pastoris: purification and characterization. Protein Expr Purif, 2006, 49: 9-14 